\title{
A NON-LINEAR MODEL BASED FEED FORWARD FLATNESS CONTROL APPROACH TO SPEED GOVERNOR SYSTEMS OF HYDROPOWER PLANTS
}

\author{
İlhan Koşalay, Derya Özkaya
}

Professional paper

This study is a part of a refurbishment project, which renews the hydro-mechanical speed governor of a hydroelectric power plant (HEPP) with a new digital one. Based on the previous study of the project, which covers the validation of the HEPP model, the simulation studies implemented in Matlab/Simulink environment are conducted to design the best controller philosophy for the digital speed governor controller. In order to be able to give satisfactory response to the load frequency control of the power system, the speed governor should respond to the set point changes as quickly as possible within the safe margins. In order to compensate unsatisfactory performance indices of conventional proportional-integral (PI) controller, a new controller based on the differential flatness theory is designed. The new controller is constructed by adding on a flatness-based feed forward part to the existing PI feedback controller, which results in improved performance compared to the conventional PI controller.

Keywords: flatness-based controller; hydroelectric power plant modelling; load frequency control; speed governor

\section{Pristup reguliranju ravnomjernosti s unaprijednom spregom sustava regulatora brzine hidroelektrana zasnovan na ne- linearnom modelu}

Stručni članak

Ovo istraživanje je dio projekta sanacije kojim se hidro-mehanički regulator brzine hidroelektrane (HEPP) zamjenjuje s novim, digitalnim. Na temelju ranijeg istraživanja procjene HEPP modela, simulacijska istraživanja u Matlab/Simulink okruženju provedena su u svrhu razvijanja najbolje filozofije za proizvodnju digitalnog regulatora brzine. Kako bi se moglo ponuditi odgovarajuće rješenje za reguliranje učestalosti punjenja energetskog sustava, regulator brzine bi u okviru dopuštenih granica trebao što brže reagirati na zadane promjene. U svrhu kompenzacije pokazatelja nezadovoljavajuće performanse uobičajenog proporcionalno-integralnog (PI) regulatora, konstruiran je novi regulator zasnovan na teoriji diferencijalne ravnomjernosti. Novi je regulator konstruiran dodavanjem postojećem PI regulatoru povratne sprege na ravnomjernosti zasnovan dio unaprijedne sprege. Rezultat je bolji rad nego s konvencionalnim PI regulatorom.

Ključne riječi: modeliranje hidroelektrane; regulator brzine; regulator brzine punjenja; regulator zasnovan na ravnomjernosti

\section{Introduction}

The balance between the generation and the consumption of the power is a critical issue in a power system and HEPPs, similar to other generation plants, which has an important role in providing the active and reactive power balance by participating to load frequency control of the power system. The load frequency control of the power system consists of a sequence of several control loops: primary, secondary and tertiary control.

In the case of any disturbance in the power system, initially the primary control loop gives the response and tries to keep the system frequency between the predetermined levels. By the help of the primary control loop the deviation in the frequency is stopped and is brought to the nominal level. In order to keep the frequency in the nominal level after the primary control loop response the secondary and tertiary control responses should be activated.

The generation in large interconnected systems, comprised of several areas, is constituted of thermal, nuclear, hydro and gas power plants. The gas power plants give the best responses to the deviation in the load demands and meet the peak demands, due to not being prevalent in the system cannot participate to the load frequency control of the system. The nuclear plants are loaded at their base levels to get the maximum efficiency and are not included in the load frequency control. Because of these reasons the automatic generation control (AGC), which controls the power transmissions between the areas of the interconnected system, is implemented over thermal and hydro power plants.

The system operators consider the generation rate constraints (GRC) of the units while generating the AGC signals. While the GRC of a typical thermal power plant is about $3 \% / \mathrm{min}$ due to the mechanical and thermal stresses, this value reaches $270 \% / \mathrm{min}$ for loading and $360 \% / \mathrm{min}$ for load shedding in hydro power plants.

Through these reasons HEPPs requires high availability for power system quality. Refurbishment projects on aged HEPPs, which consist of renewing the hydro-mechanical speed governors by a digital one, are implemented in order to increase the uptime of the plant by improving the control systems quality and availability. A mathematical model of the power plant and the control system requires to be simulated before the actual implementation of the new digital speed governor on site, in order not to cause unintended outages, to avoid unexpected controller behaviour causing water hammer effect, which is investigated in study [1] in which the pipelines of the closed conduits are modelled by using the energy approach, or runaway of the turbine, to test special modes of the controller such as isolated speed-control mode.

In order to study the hydraulic transients in hydroelectric power plants, in study [2] the plant is modelled using the equivalent electrical circuit of the pipe elements including inductance, resistance and capacitance by using the fundamental equations of motion and continuity. In [3], to investigate the effects of the frequency changes during the transient cases a hydro 
turbine model is used together with a frequency dependent synchronous generator model, induction machine model, excitation and voltage regulator system models; and the overall system model is validated through the field test measurements, including generator load start up and load rejection cases. Several models are studied in [4] and while constructing the non-linear models, the travelling wave effect is included and various cases derived, either the surge tank is integrated or not and the elastic or inelastic water column included. To determine in which cases the surge tank should be included to the model, simulations for the transient conditions are implemented. Beside these investigations a hydroelectric power plant with more than one unit sharing a common penstock is also modelled and the effects of the turbines to each other are also investigated.

The leakage problem of the wicket gates, which causes the turbine to rotate at a speed higher than the rated value, is achieved by a discreet PI controller in [5]. The comparison between the conventional controller and the new digital controller of a Kaplan turbine is performed in study [6]; the new controller controls the servomotors of the turbine according to the real time measurements of deviation in speed, net head, wicket gate opening, runner blade position, and terminal voltage and current of the excitation system. The over speed control of a Pelton turbine deflector is investigated in study [7]. The PID feedback controller is replaced with a lower gain PI feedback controller and an adaptive feed forward controller which is activated according to the frequency and acceleration threshold values.

The flatness theory helps to control nonlinear systems effectively, namely if a nonlinear system is flat then the whole system can be characterised by the derivatives of the flat output which prevents from linearization of the system. In addition to this, the trajectory filter used to trace the target output provides smooth transients between the equilibrium points which improve the transient response of the system.
Flatness based control of the trajectory of a voltage source converter is compared with the traditional PI feedback controller in study [8]. By this approach the non-linear model is directly implemented instead of a linear approximation. The disturbances, model errors and tracking errors are compensated by an additional closed loop control. The flatness approach is used in the open loop control of the system and this control balances the system between two equilibrium points and thanks to the flatness based controller, the transition between the equilibriums is performed faster and smoother with less oscillation and overshoot. The control of an automotive solenoid valve which is used for the gas exchange in combustion engines is investigated in study [9] and flatness based feedback control is compared with a PI controller. As a result of the study the flatness based control presents a robust performance though it is activated later in the valve motion than PI controller, the reference velocity of the armature is being followed with a smaller error with the flatness based controller than the PI controller. The conventional PI controller of the intermediate DC-bus voltage of an AC/DC converter is replaced with a flatness based controller of the power factor correction stage of a $\mathrm{AC} / \mathrm{DC}$ boost converter in study [10], resulting with a faster response at the regulation of the output voltage and a higher duty ratio of the full bridge converter. The static feed forward part of the conventional PI controller is replaced with a dynamic feed forward control based on differential flatness theory in the control of a pumped storage power plant in study [11] resulting with the critical oscillations on pressure being prevented.

The study is organised as follows: The system model of the HEPP and the validation of it is given in Section 2. Then, the structures of the compared controllers are explained in Section 3. Subsequently in Section 4, the results of the simulation implemented in Matlab/Simulink environment are compared. Finally, the conclusion of the research is summarised in Section 5.

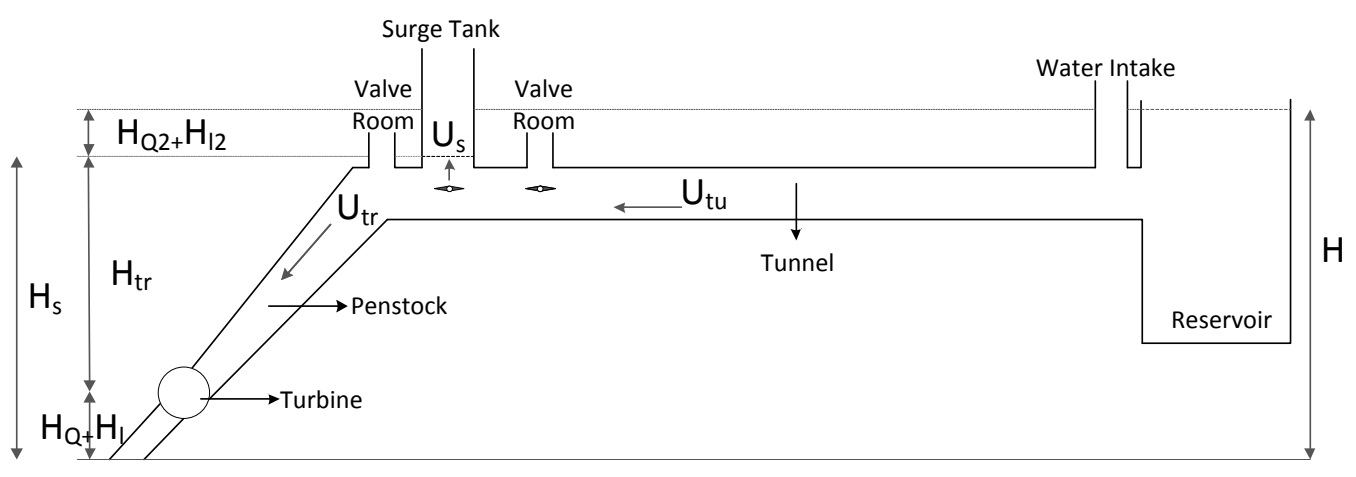

Figure 1 Main Components of Closed Conduit of Kadincik II HEPP

\section{System model}

The main components of the closed conduit of Kadincik II HEPP, consists of a single 56 MW Francis turbine shown in Fig. 1.

The system model of the power plant is built based on the equations of tunnel, penstock and surge tank dynamics together with the rotor dynamics and the validation of the model (Fig. 2, Fig. 3) is done through the field test measurements [12].

The dynamics of a typical HEPP can be expressed by

$$
\begin{aligned}
& \frac{\mathrm{d} U_{\mathrm{tu}}}{\mathrm{d} t}=\frac{H-H_{\mathrm{s}}-H_{12}}{T_{\mathrm{WS}}}, \\
& H_{12}=f_{2} \cdot U_{\mathrm{tu}}^{2},
\end{aligned}
$$


$\frac{\mathrm{d} H_{\mathrm{s}}}{\mathrm{d} t}=\frac{U_{\mathrm{tu}}-U_{\mathrm{tr}}}{C_{\mathrm{s}}}$,

$\frac{\mathrm{d} H_{\mathrm{tr}}}{\mathrm{d} t}=\frac{H_{\mathrm{s}}-H_{\mathrm{tr}}-H_{1}}{T_{\mathrm{WP}}}$,

$H_{1}=f_{1} \cdot U_{\text {tr }}^{2}$,

$U_{\mathrm{tr}}=G \cdot \sqrt{H_{\mathrm{tr}}}$

$P_{\text {elec }} \approx P_{\text {mech }}=H_{\text {tr }} \cdot\left(U_{\text {tr }}-U_{\mathrm{NL}}\right)$,

where: $U_{\mathrm{tu}}$ - velocity of water in tunnel $(\mathrm{pu}) ; H$ - reservoir level (pu); $H_{\mathrm{s}}$ - surge tank level (pu); $H_{12}$ - loss in tunnel (pu); $T_{\mathrm{wS}}$ - water starting time of tunnel (s); $f_{2}$ - head loss coefficient of tunnel $(\mathrm{pu}) ; U_{\mathrm{tr}}$ - velocity of water in turbine (pu); $C_{\mathrm{s}}$ - storage constant of surge tank (s); $T_{\mathrm{WP}}-$ water starting time of penstock $(\mathrm{s}) ; H_{\text {tr }}-$ turbine level $(\mathrm{pu}) ; \mathrm{H}_{1}$ - loss in penstock (pu); $f_{1}$ - head loss coefficient of penstock (pu); $G$ - guide vane opening (pu); $A$ efficiency of turbine.

The water starting time of the related conduit represents the time required to accelerate the flow from zero to rated flow under nominal base [13], and the storage constant of surge tank depends on the area of the surge tank and the nominal base/flow ratio.

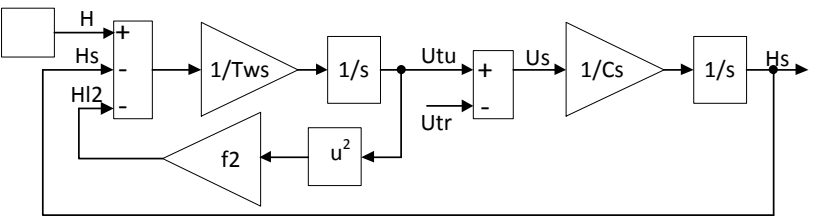

Figure 2 Block diagram of Eqs. (1) $\div$ (3)

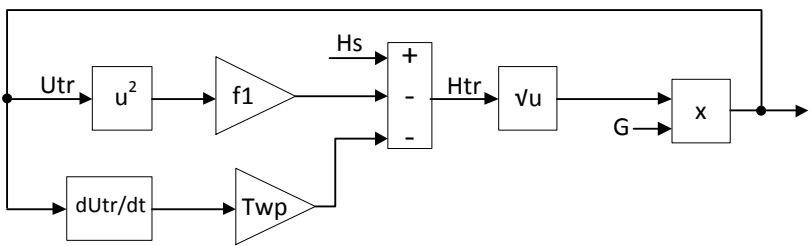

Figure 3 Block diagram of Eqs. (4) $\div(6)$

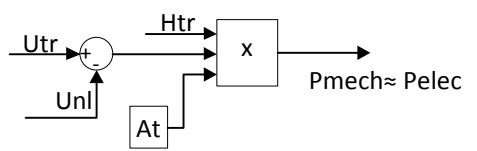

Figure 4 Block diagram of Eq. (7)

Because of the old technology built in the plant for measuring the active power, voltage transducers are used during the field test to obtain signal levels convenient for today's technology, the inadequate accuracy of the transducer caused small vibrations at the active power measurements (Fig. 2, Fig. 3).

\section{Control system}

The control of the generated active power of the plant is achieved by the guide vane opening which regulates the water flow into the turbine. The output of the controller is used to adjust the guide vane position via a regulation ring. The servomotors coupled to the regulation ring are driven by a proportional valve. The position of the valve, thus the servomotor, the regulation ring and the guide vanes positions are controlled by regulating the input of the proportional valve.
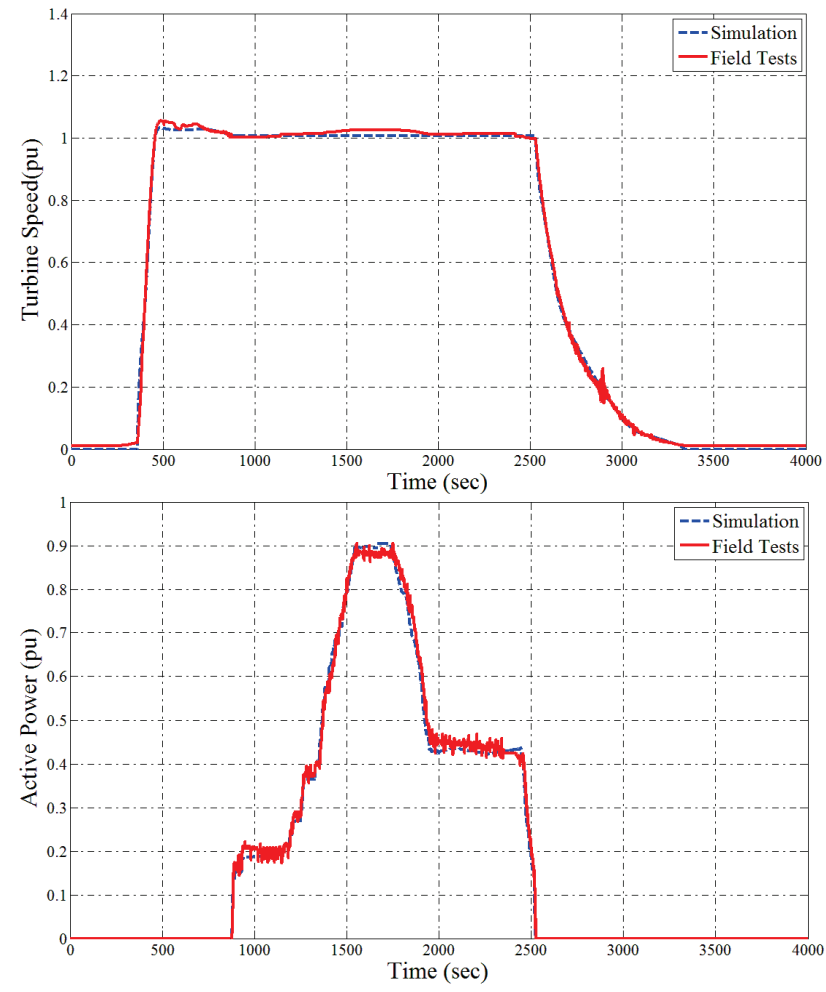

Figure 5 Turbine speed and active power graphs under normal operating conditions
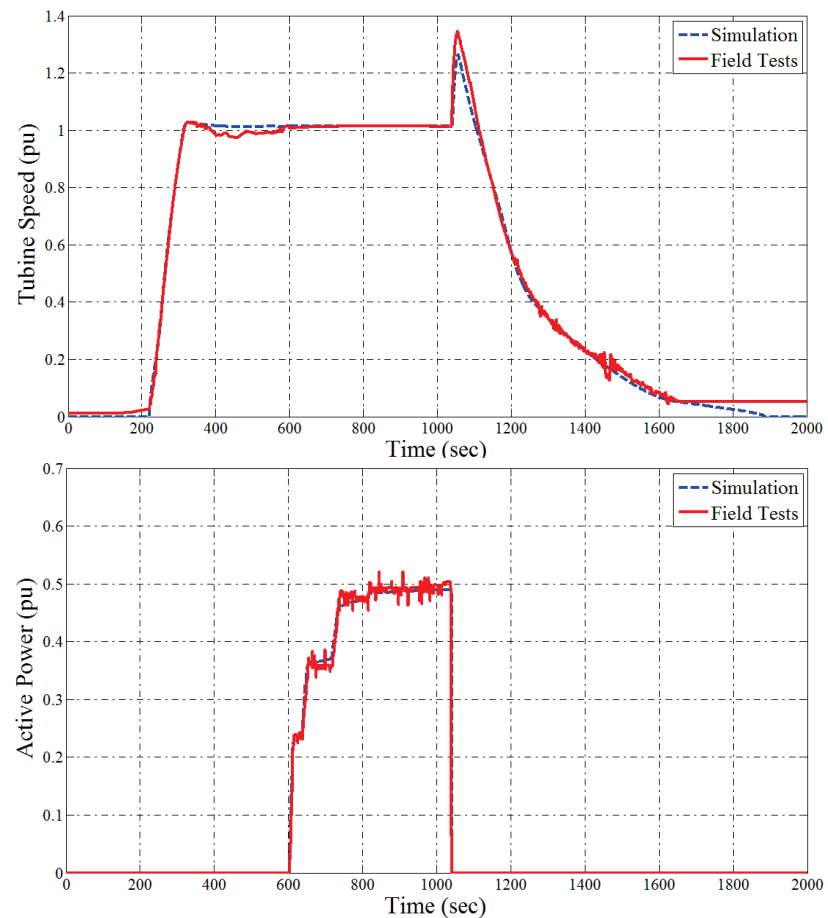

Figure 6 Turbine speed and active power graphs at load rejection while the unit is loaded at $50 \%$ of its MVA rating

\subsection{PI controller}

In order to determine the parameters of the PI controller (Fig. 4), namely the proportional gain $K_{\mathrm{p}}$ and integral time $T_{\mathrm{i}}$, the closed-loop method of ZieglerNichols Rules is implemented. A step change is applied for different proportional gains. The critical gain, $K_{\mathrm{cr}}$, 
which causes sustained oscillations at the output firsttime, and the corresponding period, $P_{\mathrm{cr}}$, are determined [14].

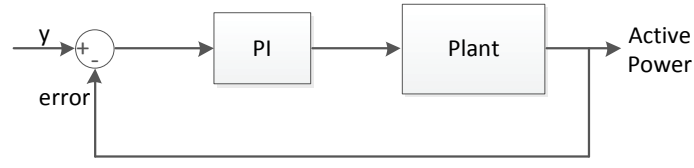

Figure 7 PI Controller structure

After determining the critical gain and critical period, corresponding proportional and integral gains are calculated using formulas in Eq. (8) and Eq. (9), resulting in $K_{\mathrm{p}}=0,01$ and $T_{\mathrm{i}}=0,0385$.

$$
\begin{aligned}
& K_{\mathrm{p}}=0,45 K_{\mathrm{cr}}, \\
& T_{\mathrm{i}}=\frac{1}{1,2} P_{\mathrm{cr}} .
\end{aligned}
$$

\subsection{Flatness based feed forward controller}

Differential flatness theory can be used while representing the non-linear systems in terms of the state variables and its derivatives with respect to time. A system is said to be differentially flat if and only if all of the state variables and the control input of the system can be expressed in terms of a flat output and its derivatives.
All of the state variables of the system given through the Eqs. $(1) \div(7)$ can also be written in terms of the water flow in tunnel and its derivatives, which makes this variable the flat output of the system.

$$
\begin{aligned}
& U_{\mathrm{tu}}=z, \\
& H_{\mathrm{s}}=H-H_{12}-T_{\mathrm{WS}} \cdot \dot{z}, \\
& U_{\mathrm{tr}}=z+2 \cdot C_{\mathrm{s}} \cdot f_{2} \cdot z \cdot \dot{z}+T_{\mathrm{WS}} \cdot C_{s} \cdot \ddot{z}, \\
& G=\frac{U_{\mathrm{tr}}}{\sqrt{H_{s}-f_{1} \cdot U_{t r}^{2}-T_{\mathrm{WP}} \cdot U_{\mathrm{tr}}}} .
\end{aligned}
$$

In order to achieve an improved performance on tracking the set point changes, an additional feed forward loop is integrated to the existing PI controller. In the new structure of the controller (Fig. 5), the feedback PI part will help to the stability of the system.

The trajectory function of the flat output is formed by the active power set point change of the system from the initial value $y_{0}=P_{0}$ to final value $y_{\mathrm{T}}=P_{\mathrm{T}}$. The corresponding flat output values are calculated by taking into account the initial conditions of the system and the differentiability of the flat output. This means that the derivatives of the flat output equal to zero at equilibrium points, $y_{0}=P_{0}$ and $y_{\mathrm{T}}=P_{\mathrm{T}}$.

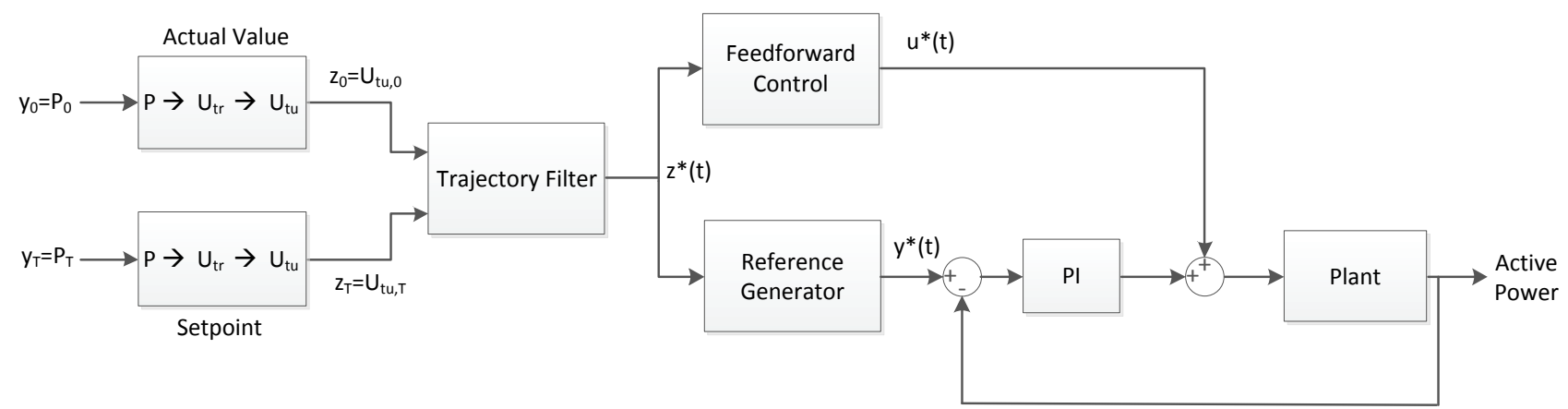

Figure 8 Flatness-based feed forward controller structure

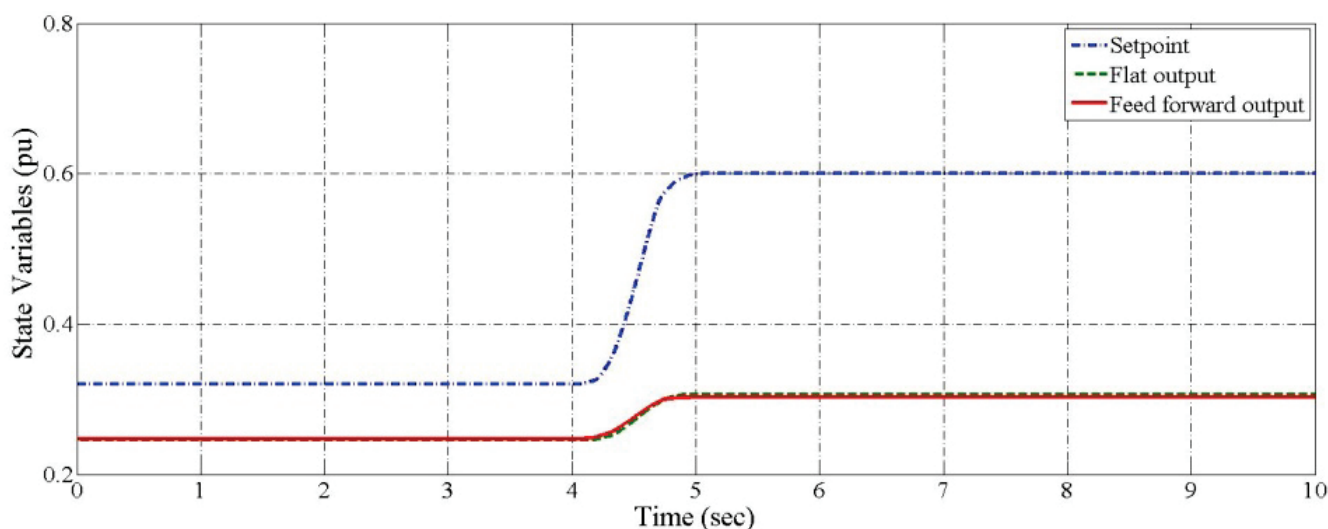

Figure 9 The trajectory function of the flat output with corresponding feed-forward loop output and setpoint to the PI controller

The trajectory function of the flat output, which is the key point, is designed to be as smooth as possible so as not to cause hydro-mechanical problems in the closed conduit of the plant due to the non-minimum phase nature of the system. So the gradient of the setpoint change should be kept in limit values.
After obtaining the trajectory function of the flat output, $z^{*}(t)$, the output of the feed-forward loop and the set point, will be used as the input to the PI controller (Fig. 6) is calculated by the Eqs. (10) $\div(13)$ 


\section{Comparison of results}

In order to compare the behaviour of the controllers (Fig. 4 and Fig. 5) same step change is applied to the input of the models, namely from 0,32 pu active power output to 0,60 pu active power output.

In Fig. 7 the actual set point change is shown together with the related PI controller response. Also the reference generator output, which is the set point of PI feedback loop calculated according to the step change, of the feed forward controller and the corresponding Flatness-based feed forward controller response is shown.

The Flatness-based feed forward controller shows better performance than the PI controller. The rise time of the system is improved by $34,9 \%$, the settling time by $18,12 \%$ and the delay time by $7,13 \%$. Beside these, the inverse response of the system, caused by the dynamic response of the system against the step changes, is improved by $18,27 \%$.

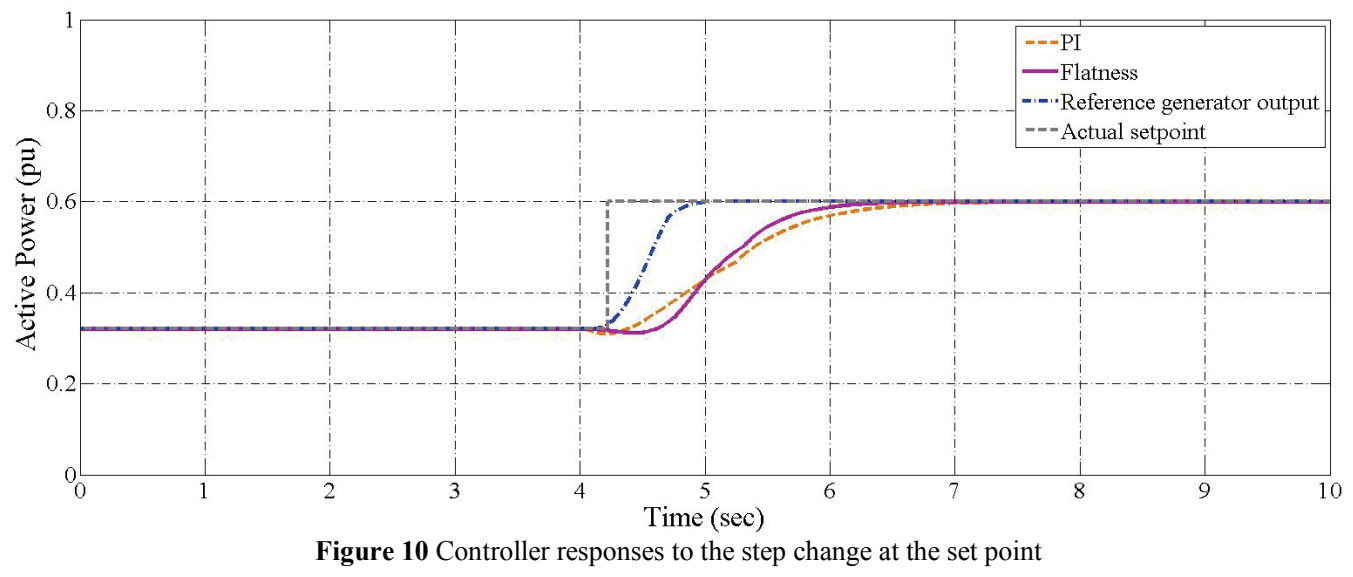

\section{Conclusion}

The mechanical speed governor of an aged HEPP will be refurbished with a new digital one and the controller of the speed governor will be designed. In order to determine the best controller for the plant the system model is constructed and simulation studies are implemented in Matlab/Simulink environment. The conventional PI controller is compared with a two degree controller structure which consists of a flatness-based feed forward part and a PI feedback loop. The latter controller resulted in better performance than the PI controller in rise time, settling time and delay time as well as undershoots of the system.

\section{Acknowledgements}

The research work was supported by no. 5132811 TUBITAK MAM Energy Institute project: "Kadincik I and II HEPP Rehabilitation Project". The authors would like to kindly thank TUBITAK MAM.

\section{References}

[1] Gjetvaj, G.; Tadic, M. The effect of water hammer on pressure increases in pipelines protected by an air vessel. // Technical Gazette. 21, 3(2014), pp. 479-484.

[2] Souza, O. H.; Barbieri, N.; Santos, A. H. M. Study of hydraulic transients in hydropower plants through simulation of nonlinear model of penstock and hydraulic turbine mode. // IEEE Transactions on Power Systems. 4(1999), pp. 1269-1272. https://doi.org/10.1109/59.801883

[3] Dai, J. J.; Shokooh, D. X. F.; Schaeffer, C.; Benge, A. Emergency generator start up study of a hydro turbine unit for a nuclear generation facility. // IEEE Transactions on Industry Applications. 40, 5(2004), pp. 1191-1199. https://doi.org/10.1109/TIA.2004.834035
[4] Working Group. Hydraulic turbine and turbine control models for system dynamic studies. // IEEE Transactions on Power Systems. 7, 1(1992), pp. 167-179. https://doi.org/10.1109/59.141700

[5] Doan, R. E.; Natarajan, K. Modelling and control design for governing hydroelectric turbines with leaky Wicket gates. // IEEE Transactions on Energy Conversion. 19, 2(2004), pp. 449-455. https://doi.org/10.1109/TEC.2004.827036

[6] Dobrijevic, D. M.; Jankovic, M. V. An approach to the damping of local modes of oscillations resulting from large hydraulic transients. // IEEE Transactions on Energy Conversion. 14, 3(1999), pp. 754-759. https://doi.org/10.1109/60.790947

[7] Johnson, R. M.; Chow, J. H.; Dillon, M. V. Pelton turbine deflector over speed control for a small power system. // IEEE Transactions on Power Systems. 19, 2(2004), pp. 1032-1037. https://doi.org/10.1109/TPWRS.2004.825918

[8] Song, E.; Lynch, A. F.; Dinavahi, V. Experimental validation of nonlinear control for a voltage source converter. // IEEE Transactions on Control Systems Technology. 17, 5(2009), pp. 1135-1144. https://doi.org/10.1109/TCST.2008.2001741

[9] Chung, S. K.; Koch, C. R.; Lynch, A. F. Flatness-based feedback control of an automotive solenoid valve. // IEEE Transactions on Control Systems Technology. 15, 2(2007), pp. 394-401. https://doi.org/10.1109/TCST.2006.886440

[10] Pahlevaninezhad, M.; Das, P.; Drobnik, J.; Jain, P. K.; Bakhshai, A. A new control approach based on the differential flatness theory for an $\mathrm{AC} / \mathrm{DC}$ converter used in electric vehicles. // IEEE Transactions on Power Electronics. 27, 4(2012), pp. 2085-2103. https://doi.org/10.1109/TPEL.2011.2170098

[11] Treuer, M.; Weissbach, T.; Hagenmeyer, V. Flatnessbased feedforward in a two-degree-of-freedom control of a pumped storage power plant. // IEEE Transactions on Control Systems Technology. 19, 6(2011), pp. 1540-1548. https://doi.org/10.1109/TCST.2010.2089523

[12] Murat, D.; Kosalay, I.; Gezer, D.; Şahin, C. Validation of hydroelectric power plant model for speed governor development studies. $/ / 4^{\text {th }}$ International Conference on 
Renewable Energy Research and Applications (ICRERA) / Italy, 2015. https://doi.org/10.1109/ICRERA.2015.7418709

[13] Energy Development \& Power Generation Committee. IEEE Guide for the application of turbine governing systems for hydroelectric generating units. // IEEE Std 1207-2011 Redline, (2011), pp. 1-139.

[14] Ogata, K. Modern control engineering. Upper Saddle River: NJ Prentice-Hall, 2010.

\section{Authors' addresses}

Illhan Koşalay, Assoc. Prof.

Ankara University,

Electrical and Electronics Engineering Department

Bölümü Gölbaș1 50. Yı1l Yerleşkesi

06830 Gölbaşı, Ankara, Turkey

E-mail: ilhan.kosalay@ankara.edu.tr

Derya Özkaya

Enerji Enstitüsü Ankara Birimi

(Energy Institute Ankara Unit),

TÜBITAK MAM (TUBITAK MRC),

ODTÜ Yerleskesi 06531 Ankara,

(METU Campus 06531 Ankara), Turkey

E-mail: derya.ozkaya@tubitak.gov.tr 